\title{
UROPROTECTIVE MECHANISMS OF NATURAL PRODUCTS AGAINST CYCLOPHOSPHAMIDE-INDUCED URINARY BLADDER TOXICITY: A COMPREHENSIVE REVIEW
}

\author{
Iman O. Sherif $\bowtie$ \\ Emergency Hospital, Faculty of Medicine, Mansoura University \\ Mansoura 35516, Egypt
}

\begin{abstract}
One of the widely used anticancer drugs for the treatment of various neoplasms is cyclophosphamide (CYP). The inactive prodrug CYP is metabolized by cytochrome P450 enzyme into active metabolites, phosphoramide mustard and acrolein. The accumulation of acrolein metabolite inside the urothelium results in hemorrhagic cystitis (HC) which is a urotoxic adverse effect associated with the use of CYP. To counteract the occurrence of HC induced by CYP, Mesna is usually used, with allergic reactions reported in some cases. Therefore, several natural products have drawn much attention as alternative safe therapies to reduce the urotoxicity produced from the use of CYP. This review will focus on certain uroprotective mechanisms related to some medicinal plants that are used to ameliorate the CYP-induced urotoxicity in experimental models. The mechanisms involving oxidative stress, inflammation, immune system, apoptosis, DNA fragmentation, uroplakins, purinergic signaling and muscarinic receptors, and CytoP450 metabolism are discussed.
\end{abstract}

Keywords: cyclophosphamide, hemorrhagic cystitis, pathogenesis, oxidative stress, inflammation, natural products

\section{INTRODUCTION}

Cyclophosphamide (CYP) is a well-known alkylating agent that is used in the treatment of both malignant and nonmalignant disorders. CYP is an inactive prodrug and requires cytochrome $\mathrm{P} 450$ (CytP450) to be metabolized in the liver, forming active metabolites, phosphoramide mustard and acrolein (Al-Yahya et al., 2009) as shown in Figure 1. The cytotoxicity of CYP results from the ability of these metabolites to react and alkylate DNA causing cell damage (Sakthivel and Guruvayoorappan, 2015).

Acrolein metabolite is accumulated in the bladder (Matz and Hsieh, 2017), leading to urotoxicity via its direct contact with the uroepithelium (Manikandan et al., 2010). Ulceration, nausea, nephrotoxicity, hepatotoxicity, and pulmonary fibrosis are other side effects also reported after CYP administration (Sakthivel and Guruvayoorappan, 2015).

Hemorrhagic cystitis (HC) is a serious side effect accompanying the use of CYP, as evident in studies involving both animals and humans (Saito et al., 2018; Sherif et al., 2016). Hemorrhagic cystitis - HC is known as a diffused inflammation in the urinary bladder leading to bladder mucosa bleeding, and usually arises from using oxazaphosphorine chemotherapy like CYP and ifosfamide (Manikandan et al., 2010). Damage of the bladder urothelium, formation

区emyosh@yahoo.com, https://orcid.org/0000-0002-9487-3456 


\section{Cyclophosphamide (CYP)}

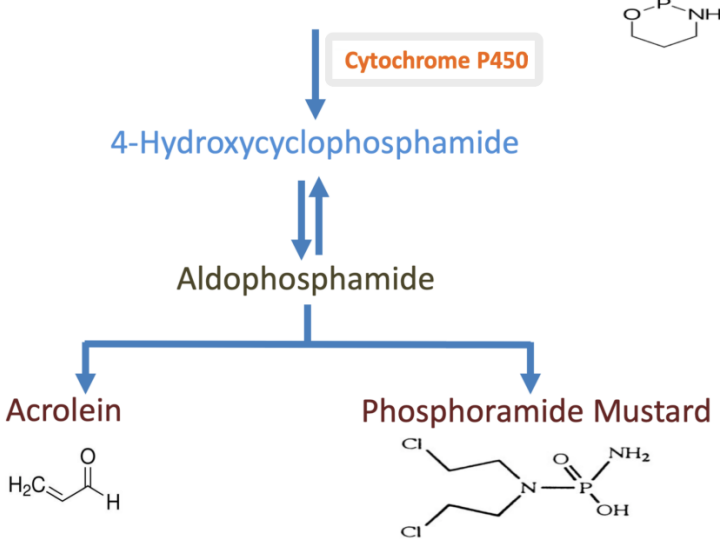

Fig. 1. The hepatic metabolism of cyclophosphamide

of a blood clot, and edema are signs of the incidence of $\mathrm{HC}$ (Abdi et al., 2016). A mortality rate between $2 \%$ and $4 \%$ in patients suffering from $\mathrm{HC}$ was reported in patients with massive bladder hemorrhage when using a high dose of intravenous CYP (Manikandan et al., 2010).

Moreover, cystitis induced by CYP can lead to an overactive bladder which is associated with urothelium damage and severe inflammation (Büyüknacar et al., 2008; Eser et al., 2012; Sherif, 2018). In the detrusor, acetylcholine (Ach) acts on muscarinic receptors leading to contraction of the urinary bladder via the parasympathetic nervous system (Aronsson et al., 2012). Therefore, researchers have searched for therapeutic agents to target inflammation and improve bladder activity (Büyüknacar et al., 2008; Eser et al., 2012; Sherif, 2018).

Detoxification of CYP to reduce its urotoxicity can be achieved by vigorous diuresis and using Mesna (Kyung et al., 2011). Mesna has a well-known structure of 2-mercaptoethanesulfonate sodium and is the only approved drug for CYP-induced HC which detoxifies acrolein metabolite inside the urinary tract by binding to it through its sulfhydryl group, producing inert non-toxic thioether, which does not induce uroepithelium damage (Kątnik-Prastowska et al., 2014; Ozcan et al., 2005). However, Mesna does not eradicate $\mathrm{HC}$ symptoms completely and, at the same time, is not effective in some cases and was reported to cause hypersensitivity reactions ranging from mild dermatological effects to systemic anaphylactic reactions (Robertson and Clark, 2016).

Therefore, researchers are searching for novel therapeutics with more attention on the use of natural products to lessen the HC induced by CYP. Thus, this review focuses on the role of some natural products in ameliorating the urinary bladder toxicity induced by CYP and further explores their molecular uroprotective mechanism.

\section{Uroprotective mechanisms of some natural products used in models of CYP-induced urotoxicity}

It has been documented that many natural products exert their uroprotective effects through acting on different mechanisms, as illustrated in Figure 2, which has been implicated in the pathophysiology of CYP-induced HC. This review assembled some of the reported natural products with proved uroprotective effect against CYP-induced HC, as shown in Table 1, and discussed their uroprotective actions through the modulation of oxidative stress, inflammation, immune system, apoptosis, DNA fragmentation, uroplakins, purinergic signaling and muscarinic receptors, and CytP450 metabolism.

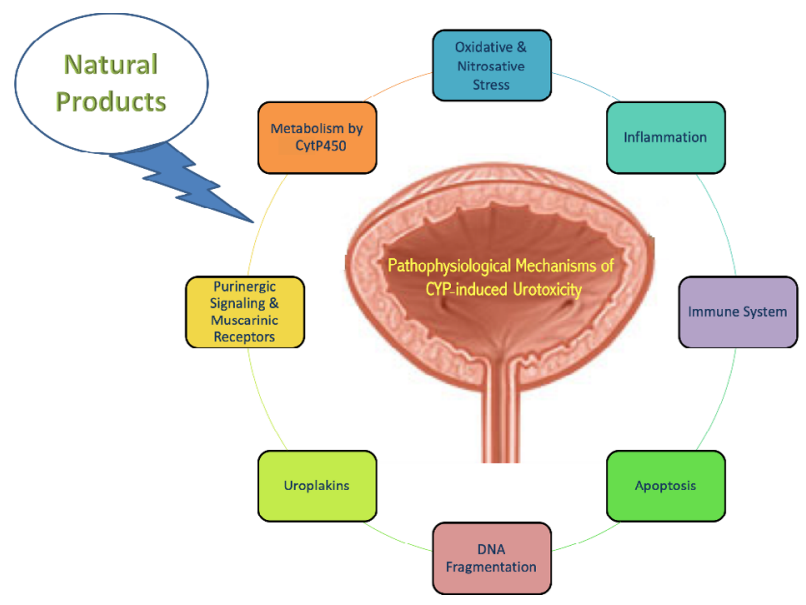

Fig. 2. Certain pathophysiological mechanisms of cyclophosphamide-induced urotoxicity and the possible uroprotective mechanisms of some natural products 
Sherif, I. O. (2020). Uroprotective mechanisms of natural products against cyclophosphamide-induced urinary bladder toxicity: A comprehensive review. Acta Sci. Pol. Technol. Aliment., 19(3), 333-346. http://dx.doi.org/10.17306/J.AFS.2020.0832

Table 1. List of some natural products with uroprotective effects in animal models of CYP induced-urotoxicity

\begin{tabular}{|c|c|c|c|}
\hline $\begin{array}{l}\text { Natural product / } \\
\text { Treatment regimen }\end{array}$ & $\begin{array}{l}\text { CYP-induced HC } \\
\text { model }\end{array}$ & Outcomes & References \\
\hline 1 & 2 & 3 & 4 \\
\hline $\begin{array}{l}\text { Acacia senegal gum exudate, } \\
\text { Gum Arabic }(\mathrm{GA}) 7.5 \mathrm{~g} / \mathrm{kg} / \text { day } \\
\text { in drinking water for } 6 \text { days }\end{array}$ & $150 \mathrm{mg} / \mathrm{kg}$ ip / Rat & $\begin{array}{l}\text { GA treatment resulted in: } \\
-\downarrow \text { bladder MDA level } \\
-\uparrow \text { bladder GSH level } \\
-\downarrow \text { bladder NO content } \\
-\uparrow \text { bladder contractile response to Ach }\end{array}$ & $\begin{array}{l}\text { Al-Yahya et al. } \\
(2009)\end{array}$ \\
\hline $\begin{array}{l}\text { Oleuoropein (Oleu) } \\
30 \mathrm{mg} / \mathrm{kg} / \text { day by oral gavage } \\
\text { for } 10 \text { days }\end{array}$ & $\begin{array}{l}150 \mathrm{mg} / \mathrm{kg} \text {, a single } \\
\text { ip / Rat }\end{array}$ & $\begin{array}{l}\text { Oleu treatment resulted in: } \\
-\downarrow \text { bladder NO level } \\
-\uparrow \text { bladder GSH, CAT level } \\
-\downarrow \text { bladder TNF- } \alpha \text {, VEGF, ICAM-1 mRNA } \\
\quad \text { expression }\end{array}$ & Sherif et al. (2016) \\
\hline $\begin{array}{l}\text { Quercetin (Quer) } \\
50 \mathrm{mg} / \mathrm{kg} / \text { day for } 10 \text { days }\end{array}$ & $\begin{array}{l}150 \mathrm{mg} / \mathrm{kg} \text {, a single } \\
\text { ip / Rat }\end{array}$ & $\begin{array}{l}\text { Quer treatment resulted in: } \\
-\downarrow \text { bladder MDA \& NO level } \\
-\uparrow \text { bladder SOD, CAT level } \\
-\downarrow \text { bladder TNF- } \alpha \text {, IL-6 level } \\
-\uparrow \text { bladder IL-10 level } \\
-\downarrow \text { bladder COX-2 mRNA expression }\end{array}$ & Sherif (2018) \\
\hline $\begin{array}{l}\text { Resveratrol } \\
20 \text {, 40, and } 80 \mathrm{mg} / \mathrm{kg} \text { in } 2-\mathrm{ml} \\
\text { saline, } 20 \mathrm{~min} \text { before CYP, ip }\end{array}$ & $150 \mathrm{mg} / \mathrm{kg}$ ip / Rat & $\begin{array}{l}\text { RES treatment resulted in: } \\
-\downarrow \text { blood MDA level } \\
-\uparrow \text { blood GSH level } \\
-\uparrow \text { erythrocyte CAT, GPx, SOD level } \\
-\uparrow \text { serum ascorbic acid } \\
-\downarrow \text { serum TNF- } \alpha \text { level } \\
-\uparrow \text { serum IL-10 level }\end{array}$ & Keles et al. (2014) \\
\hline $\begin{array}{l}\text { Curcumin } \\
200 \mathrm{mg} / \mathrm{kg} \text {, ip for } 10 \text { days }\end{array}$ & $\begin{array}{l}150 \mathrm{mg} / \mathrm{kg}, \text { ip single } \\
\text { dose / Rat }\end{array}$ & $\begin{array}{l}\text { Curcumin treatment resulted in: } \\
-\downarrow \text { serum TNF- } \alpha \text { level } \\
-\downarrow \text { bladder MPO level } \\
-\downarrow \text { urinary NO level } \\
-\uparrow \text { bladder ATP level } \\
-\uparrow \text { bladder GSH \& GST level } \\
-\downarrow \text { bladder MDA level }\end{array}$ & Arafa (2009) \\
\hline $\begin{array}{l}\text { Diallyl disulfide (DADS) } \\
100 \mathrm{mg} / \mathrm{kg} / \text { day for } 5 \text { days }\end{array}$ & $\begin{array}{l}100 \mathrm{mg} / \mathrm{kg} / \text { day single } \\
\text { ip / Rat }\end{array}$ & $\begin{array}{l}\text { DADS treatment resulted in: } \\
-\downarrow \text { bladder MDA level } \\
-\uparrow \text { bladder GSH, GR, GST, CAT levels } \\
-\downarrow \text { bladder Caspase-3 \& TUNEL protein } \\
\quad \text { expression } \\
-\downarrow \text { bladder acrolein positive cells } \\
-\uparrow \text { bladder Nrf2, NQO-1, and HO-1 protein } \\
\quad \text { expression } \\
-\uparrow \text { hepatic microsomal Cyp2B1/2 \& Cyp3A1 } \\
\quad \& \downarrow \text { Cyp } 2 \text { C11 protein expression }\end{array}$ & Kim et al. (2014) \\
\hline $\begin{array}{l}\text { Ethanol extract of the inner bark } \\
\text { of Caesalpinia pyramidalis } \\
\text { (Tul.) (EECp) } \\
(100,200 \text { or } 400 \mathrm{mg} / \mathrm{kg}) \\
1 \text { hour prior to injection of cyp }\end{array}$ & $\begin{array}{l}\text { (200 mg/kg, } 5 \mathrm{~mL} / \mathrm{kg} \text {, } \\
\text { ip) / Rat }\end{array}$ & $\begin{array}{l}\text { EECp treatment resulted in: } \\
-\downarrow \text { bladder MPO level } \\
-\downarrow \text { serum NOx level }\end{array}$ & Moraes et al. (2013) \\
\hline
\end{tabular}


Sherif, I. O. (2020). Uroprotective mechanisms of natural products against cyclophosphamide-induced urinary bladder toxicity: A comprehensive review. Acta Sci. Pol. Technol. Aliment., 19(3), 333-346. http://dx.doi.org/10.17306/J.AFS.2020.0832

Table 1 cont.

\begin{tabular}{|c|c|c|c|}
\hline 1 & 2 & 3 & 4 \\
\hline $\begin{array}{l}\text { Pomegranate } \\
2 \mathrm{ml} \text { of unfiltered Pomegranate } \\
\text { Juice (PJ)/day for } 14 \text { days }\end{array}$ & $\begin{array}{l}150 \mathrm{mg} / \mathrm{kg}, \\
\text { a single ip / Rat }\end{array}$ & $\begin{array}{l}\text { PJ treatment resulted in: } \\
-\downarrow \text { bladder MDA, NO level } \\
-\downarrow \text { serum MDA level } \\
-\uparrow \text { serum TAC, GSH, CAT level } \\
-\uparrow \text { bladder TAC, CAT level } \\
-\downarrow \text { serum Protein-SH level } \\
-\downarrow \text { bladder TUNEL expression }\end{array}$ & $\begin{array}{l}\text { Mahmoudi et al. } \\
\text { (2018) }\end{array}$ \\
\hline $\begin{array}{l}\text { Moringa oleifera leaves (Mof) } \\
500 \text { and } 1000 \mathrm{mg} / \mathrm{kg} / \text { day, orally, } \\
1 \text { hour before and } 4 \text { hours after } \\
\mathrm{CP} \text {, for } 7 \text { days }\end{array}$ & $\begin{array}{l}100 \mathrm{mg} / \mathrm{kg} \text {, a single } \\
\text { intraperitoneally (ip) } \\
\text { / Rat }\end{array}$ & $\begin{array}{l}\text { Mof treatment resulted in: } \\
-\downarrow \text { bladder MDA level } \\
-\uparrow \text { bladder GSH level }\end{array}$ & Taha et al. (2015) \\
\hline $\begin{array}{l}\text { Carotene } 2 \times 20 \mathrm{mg} / \mathrm{kg} / \text { day, ip } \\
\text { Tocopherol } 2 \times 20 \mathrm{mg} / \mathrm{kg} / \text { day, ip } \\
\text { Both for } 3 \text { days, day before } \\
\text { and day after CYP }\end{array}$ & $\begin{array}{l}100 \mathrm{mg} / \mathrm{kg} \text { ip, } \\
\text { single dose / Rat }\end{array}$ & $\begin{array}{l}\text { Antioxidants treatment resulted in: } \\
-\downarrow \text { bladder MDA level }\end{array}$ & Sadir et al. (2007) \\
\hline $\begin{array}{l}\text { Spirulina } \\
1000 \mathrm{mg} / \mathrm{kg} / \text { day orally } \\
\text { for } 7 \text { days }\end{array}$ & $\begin{array}{l}150 \mathrm{mg} / \mathrm{kg}, \\
\text { a single ip / Rat }\end{array}$ & $\begin{array}{l}\text { Spirulina treatment resulted in: } \\
-\downarrow \text { bladder MDA level } \\
-\uparrow \text { bladder CAT, SOD level }\end{array}$ & $\begin{array}{l}\text { Sinanoglu et al. } \\
\text { (2012) }\end{array}$ \\
\hline $\begin{array}{l}\text { Flavonoid } \\
\text { Quercetin } \\
2 \times 20 \mathrm{mg} / \mathrm{kg} \text { and Epigallocat- } \\
\text { echin } 3 \text {-gallate (EGCG) } \\
2 \times 20 \mathrm{mg} / \mathrm{kg}\end{array}$ & $\begin{array}{l}100 \mathrm{mg} / \mathrm{kg}, \\
\text { a single ip / Rat }\end{array}$ & $\begin{array}{l}\text { Flavonoid treatment resulted in: } \\
-\downarrow \text { bladder MDA level }\end{array}$ & Ozcan et al. (2005) \\
\hline $\begin{array}{l}\text { Caffeic acid phenethyl ester } \\
\text { (CAPE) } 10 \mu \mathrm{mol} / \mathrm{kg} \text {, } \\
\text { three times ip }\end{array}$ & $\begin{array}{l}100 \mathrm{mg} / \mathrm{kg} \text { ip, } \\
\text { single dose / Rat }\end{array}$ & $\begin{array}{l}\text { CAPE treatment resulted in: } \\
-\downarrow \text { bladder SOD, CAT level } \\
-\downarrow \text { bladder MDA \& NO level }\end{array}$ & Uysal et al. (2015) \\
\hline $\begin{array}{l}\text { Viscum album (VA) } \\
250 \mathrm{mg} / \mathrm{kg} / \text { day orally } \\
\text { for } 10 \text { days and quercetin }(\mathrm{QE}) \\
50 \mathrm{mg} / \mathrm{kg} / \text { day orally for } 10 \text { days }\end{array}$ & $\begin{array}{l}40 \mathrm{mg} / \mathrm{kg} \text {, ip on } 8^{\text {th }} \\
\text { and } 9^{\text {th }} \text { days } / \text { Mice }\end{array}$ & $\begin{array}{l}\text { Products treatment resulted in: } \\
-\downarrow \text { bladder LPO, MPO level } \\
-\uparrow \text { bladder GSH level }\end{array}$ & $\begin{array}{l}\text { Sekeroğlu et al. } \\
\text { (2011) }\end{array}$ \\
\hline $\begin{array}{l}\text { Acacia ferruginea (AF) } \\
(10 \mathrm{mg} / \mathrm{kg}, \text { ip daily }) \\
\text { for } 10 \text { days }\end{array}$ & $\begin{array}{l}25 \mathrm{mg} / \mathrm{kg} / \text { day } \\
\text { for } 10 \text { days, ip / Mice }\end{array}$ & $\begin{array}{l}\text { AF treatment resulted in: } \\
-\uparrow \text { serum IL-2, IFN- } \gamma, \text { GM-CSF level } \\
-\downarrow \text { serum TNF- } \alpha \text { level } \\
-\downarrow \text { bladder LPO level } \\
-\uparrow \text { bladder GSH level }\end{array}$ & $\begin{array}{l}\text { Sakthivel and Guru- } \\
\text { vayoorappan (2015) }\end{array}$ \\
\hline $\begin{array}{l}\text { S-allyl cysteine (SAC) } \\
150 \mathrm{mg} / \mathrm{kg} / \text { day, ip for } 7 \text { days }\end{array}$ & $\begin{array}{l}200 \mathrm{mg} / \mathrm{kg} / \mathrm{day}, \mathrm{ip} \\
\text { for } 7 \text { days / Mice }\end{array}$ & $\begin{array}{l}\text { SAC treatment resulted in: } \\
-\uparrow \text { bladder UPII, UPIIIa mRNA and protein } \\
\quad \text { expressions } \\
-\downarrow \text { serum UPIIIa level } \\
-\downarrow \text { serum CCL11 level, bladder mRNA } \\
\quad \text { expression } \\
-\downarrow \text { serum TNF- } \alpha \text { level, bladder mRNA ex- } \\
\quad \text { pression and protein level }\end{array}$ & $\begin{array}{l}\text { Abdi et al. (2018) } \\
\text { Abdi et al. (2016) }\end{array}$ \\
\hline
\end{tabular}


Sherif, I. O. (2020). Uroprotective mechanisms of natural products against cyclophosphamide-induced urinary bladder toxicity: A comprehensive review. Acta Sci. Pol. Technol. Aliment., 19(3), 333-346. http://dx.doi.org/10.17306/J.AFS.2020.0832

Table 1 cont.

\begin{tabular}{|c|c|c|c|}
\hline 1 & 2 & 3 & 4 \\
\hline $\begin{array}{l}\text { Thymoquinone (TQ) } \\
5,10 \text { and } 20 \mathrm{mg} / \mathrm{kg} \text { ip twice/day, } \\
3 \text { days before and } 3 \text { days after } \\
\text { CYP }\end{array}$ & $\begin{array}{l}200 \mathrm{mg} / \mathrm{kg} \text {, a single ip } \\
\text { / Mice }\end{array}$ & $\begin{array}{l}\text { TQ treatment resulted in: } \\
-\downarrow \text { bladder DNA fragmentation } \\
-\uparrow \text { bladder Nrf2 protein expression } \\
-\downarrow \text { bladder TNF- } \alpha, \text { IL-1 } \beta \text { and IL-6 level } \\
-\downarrow \text { bladder MDA level } \\
-\uparrow \text { bladder GSH, SOD, CAT level }\end{array}$ & Gore et al. (2016) \\
\hline $\begin{array}{l}\text { Quinovic acid glycosides } \\
\text { purified fraction (QAPF) } \\
\text { from Uncaria tomentosa } \\
(20,50 \text { and } 100 \mathrm{mg} / \mathrm{kg}, \mathrm{ip}) \\
30 \mathrm{~min} \text { before CYP }\end{array}$ & $\begin{array}{l}300 \mathrm{mg} / \mathrm{kg} / \text { day single } \\
\text { ip / Mice }\end{array}$ & $\begin{array}{l}\text { QAPF treatment resulted in: } \\
-\downarrow \text { bladder MPO level } \\
-\downarrow \text { bladder IL-1 } \beta \text { level } \\
-\downarrow \text { bladder P2X7R expression }\end{array}$ & Dietrich et al. (2015) \\
\hline $\begin{array}{l}\text { Alcoholic extract Ipomoea } \\
\text { obscura (IO) } \\
10 \mathrm{mg} / \mathrm{kg} \text { ip for } 5 \text { days }\end{array}$ & $\begin{array}{l}1.5 \mathrm{mmol} / \mathrm{kg} \text { single ip } \\
\text { dose / Mice }\end{array}$ & $\begin{array}{l}\text { IO treatment resulted in: } \\
-\uparrow \text { bladder GSH level } \\
-\downarrow \text { serum and urinary protein level } \\
-\downarrow \text { serum TNF- } \alpha \\
-\uparrow \text { serum IFN- } \gamma, \text { IL-2 level }\end{array}$ & $\begin{array}{l}\text { Hamsa and Kuttan } \\
\text { (2011) }\end{array}$ \\
\hline $\begin{array}{l}\text { Tinospora cordifolia }(\mathrm{TC}) \\
\text { (F. Menispermaceae) } \\
200 \mathrm{mg} / \mathrm{kg} \text {, ip for } 5 \text { days }\end{array}$ & $\begin{array}{l}1.5 \mathrm{mmol} / \mathrm{kg} \text { single ip } \\
\text { dose / Mice }\end{array}$ & $\begin{array}{l}\text { TC treatment resulted in: } \\
-\uparrow \text { bladder GSH level } \\
-\downarrow \text { serum and urinary protein level } \\
-\downarrow \text { serum TNF- } \alpha \\
-\uparrow \text { serum IFN- } \gamma, \text { IL-2 level }\end{array}$ & $\begin{array}{l}\text { Hamsa and Kuttan } \\
(2012)\end{array}$ \\
\hline $\begin{array}{l}\text { Hydroxytyrosol (HT) } \\
100 \mathrm{mg} / \mathrm{kg} \text { orally for } 10 \text { days }\end{array}$ & $\begin{array}{l}50 \mathrm{mg} / \mathrm{kg} \text {, a single ip } \\
\text { / Mice }\end{array}$ & $\begin{array}{l}\text { HT treatment resulted in: } \\
-\downarrow \text { bladder LPO level } \\
-\downarrow \text { bladder TBARS level } \\
-\uparrow \text { bladder GSH level } \\
-\uparrow \text { bladder GST, GR, GP, CAT }\end{array}$ & Rouissi et al. (2011) \\
\hline $\begin{array}{l}\text { Cuscuta chinensis (C. chinensis) } \\
\text { (F: Convolvulaceae) } \\
10 \mathrm{mg} / \mathrm{kg} / \text { day, ip for } 10 \text { days }\end{array}$ & $\begin{array}{l}25 \mathrm{mg} / \mathrm{kg} / \text { day } \\
\text { for } 10 \text { days, ip / Mice }\end{array}$ & $\begin{array}{l}\text { C. chinensis treatment resulted in: } \\
-\uparrow \text { bladder GSH level } \\
-\downarrow \text { bladder NO level } \\
-\uparrow \text { serum GM-CSF level } \\
-\downarrow \text { serum TNF- } \alpha \text { level }\end{array}$ & Raju et al. (2015) \\
\hline
\end{tabular}

MDA - malondialdehyde, GSH - reduced glutathione, NO - nitric oxide, Ach - acetylcholine, CAT - catalase, TNF- $\alpha$ - tumor necrosis factor-alpha, VEGF - vascular endothelial growth factor, ICAM-1 - intercellular cell adhesion molecule-1, IL - interleukin, COX-2 - cyclooxygenase-2, GPx - glutathione peroxidase, MPO - myeloperoxidase, ATP - adenosine triphosphate, GST glutathione-S-transferase, GR - glutathione reductase, TUNEL - terminal deoxynucleotidyl transferase (TdT)a dUTP Nick-End Labeling, Nrf2 - nuclear factor erythroid 2-related factor 2, NQO-1 - quinone oxidoreductase-1, HO-1 - heme oxygenase-1, Cyp - cytochrome, TAC - total antioxidant capacity, LPO - lipid peroxidation, IFN- $\gamma$ - interferon-gamma, GM-CSF - granulocytemacrophage colony stimulating factor, UP - uroplakin, TBARS - thiobarbituric acid reactive substances.

\section{Role of oxidative and nitrosative stress}

Cells possess an antioxidant defense mechanism to counteract the release of reactive oxygen species (ROS). When there is a disturbance in the antioxidant defense mechanism due to excessive production of ROS, this results in a state of oxidative stress which subsequently leads to oxidative damage and cellular injury (Birben et al., 2012). Malondialdehyde (MDA) is considered as a sign of lipid peroxidation. Superoxidase dismutase (SOD) catalyzes the conversion of superoxide anion to oxygen and hydrogen peroxide then catalase (CAT) reduces the hydrogen peroxide into oxygen and water (Keles et al., 2014). These antioxidant enzymes and others act as a defense mechanism and 
Sherif, I. O. (2020). Uroprotective mechanisms of natural products against cyclophosphamide-induced urinary bladder toxicity: A comprehensive review. Acta Sci. Pol. Technol. Aliment., 19(3), 333-346. http://dx.doi.org/10.17306/J.AFS.2020.0832

could protect tissues and cells against ROS damage (Bhatia et al., 2008; Sherif, 2018). Glutathione reductase (GR) and glutathione peroxidase (GP) are vital for preserving the constant ratio of reduced glutathione (GSH) and oxidized glutathione (GSSG), thus any disturbance of the activity of these enzymes results in a disruption of the GSH cycle (Bhatia et al., 2008).

The NO toxic effect comes from its reaction with superoxide anion to form peroxynitrite that depletes the antioxidant enzymes, leading also to oxidative damage (Virág et al., 2003). Moreover, inducible nitric oxide synthase (iNOS) is reported to produce toxic NO, which is considered to be the primary source of the reactive nitrogen species (RNS) (Wang et al., 2012). During inflammation, ROS together with RNS contributes to cellular injury, oxidative damage through lipid peroxidation, and DNA damage (Topal et al., 2005).

Moreover, the nuclear factor erythroid 2-related factor 2 (Nrf2) / heme oxygenase-1 (HO-1) antioxidant pathway is involved. Under normal conditions, the redox-sensitive transcription factor Nrf2 is sequestered in the cytoplasm by Kelch-like ECH-associated protein 1 (Keap1) protein inhibitor, while under oxidative stress it is translocated into the nucleus and binds to antioxidant response elements (ARE) and induces the expression of SOD, CAT, GST, and HO-1 in addition to nicotinamide adenine dinucleotide (phosphate) $(\mathrm{NAD}(\mathrm{P}) \mathrm{H})$ and quinone oxidoreductase-1 (NQO-1) (Bryan et al., 2013).

Effects of CYP. The major role of oxidative and nitrosative stress in the pathogenesis of CYP-induced urotoxicity has been reported (Al-Yahya et al., 2009; Sherif, 2018; Sherif et al., 2016). The metabolic conversion of CYP into toxic metabolites is associated with ROS production resulting in oxidative stress, lipid peroxidation, and oxidative cell damage (Mohammad et al., 2012). In animal models of CYP-induced urinary bladder injury, several studies have shown that animals injected with CYP exhibited elevated levels of bladder lipid peroxidation (LPO) and reduced levels of bladder GSH (Arafa, 2009; Bhatia et al., 2008; Sakthivel and Guruvayoorappan, 2015), glutathione-S-transferase (GST) (Arafa, 2009), GR, GP, CAT and SOD (Bhatia et al., 2008; Kim et al., 2014), along with increased levels of bladder MDA and NO in both bladder and serum (Al-Yahya et al.,
2009; Arafa, 2009; Kim et al., 2014; Moraes et al., 2013). These results are attributed to the toxic metabolite of CYP acrolein which led to NO overproduction, and lipid peroxide formation. These products were detoxified by the antioxidant enzymes leading to their depletion (Bhatia et al., 2008). Also, in the bladder of rats treated with CYP, elevated levels of protein thiol and protein carbonyl content were observed, and the increased thiol protein could be attributed to a defensive mechanism occurring as a result of increased oxidative stress (Abraham et al., 2011).

The Nrf2/HO-1 pathway is another antioxidant pathway involved in the pathogenesis of CYP-induced urotoxicity (Kim et al., 2014). Kim et al. (2014) reported that CYP induced a marked upregulation of bladder Nrf2/HO-1/NQO-1 protein expression reporting that urotoxicity induced Nrf2 with concomitant phase II enzymes as a cytoprotective mechanism (Kim et al., 2014). A contradictory study showed decreased bladder protein expression of Nrf2 accompanied with CYP injection and explained this action through CYP metabolites, which diminish the Nrf2 activity and subsequently inhibit phase II antioxidant enzymes resulting in increased oxidative tissue damage (Gore et al., 2016). These controversial results could be attributed to different study designs including the difference in the CYP dose and the experimental animals used.

Effects of natural products. Acacia ferruginea (F: Mimosaceae) extract has various bioactive ingredients with antioxidant, antitumor and antimicrobial properties (Sakthivel and Guruvayoorappan, 2013). Reduced levels of bladder LPO and increased levels of bladder GSH were reported with $10 \mathrm{mg} / \mathrm{kg} /$ day of AF given ip for 10 days when compared with CYP treated mice, indicating its uroprotective effects (Sakthivel and Guruvayoorappan, 2015). Moreover, a natural proteoglycan called Gum Arabic, which exudates from Acacia senegal stem, showed a marked decline in bladder MDA and NO content along with a significant elevation in bladder GSH level (Al-Yahya et al., 2009).

Curcumin, with a chemical structure of (1,7-bis(4-hydroxy-3-methoxyphenyl)-1,6-heptadiene-3,5-dione, is also called diferuloylmethane and is the principal natural polyphenol of the turmeric pigment of Curcuma longa rhizome (Arafa, 2009). The administration of $200 \mathrm{mg} / \mathrm{kg}$ curcumin for 10 days resulted in 
Sherif, I. O. (2020). Uroprotective mechanisms of natural products against cyclophosphamide-induced urinary bladder toxicity: A comprehensive review. Acta Sci. Pol. Technol. Aliment., 19(3), 333-346. http://dx.doi.org/10.17306/J.AFS.2020.0832

a dramatic decrease in the bladder NO with a marked rise in GSH and GST levels compared to CYP treated group (Arafa, 2009). S-allyl cysteine (SAC), one of the active ingredients in aged garlic extract, and diallyl disulfide (DADS), another compound derived from garlic, have been shown to have beneficial pharmacological effects against various diseases, and have been reported to have uroprotective effects against CYP-induced HC. These compounds work via the restoration of bladder antioxidant enzyme levels, with marked rises in GST, GR, GP, SOD, and CAT bladder contents (Bhatia et al., 2008; Kim et al., 2014).

In models of CYP-induced urotoxicity, DADS treatment exhibited a notable upregulation of bladder Nrf2/HO-1/NQO-1 protein expression (Kim et al., 2014) and a similar result was observed with a medicinal plant derived from Nigella sativa seeds (F: Ranunculaceae) called thymoquinone which possessed an antioxidant activity and showed a marked rise in the bladder protein expression of Nrf2 (Gore et al., 2016).

\section{Role of inflammation}

Inflammation is one of the body's immunological defense mechanisms against injury characterized by the immigration of white blood cells and the production of chemical toxins. Consequently, the acute inflammatory response is rapid and is associated with a systemic response in which activation of the tissue macrophages with the release of cytokines such as interleukine-1 (IL-1), IL-6, and tumor necrosis factor-alpha (TNF- $\alpha$ ) occurred (Gulati et al., 2016). The TNF- $\alpha$ could induce expressions of the endothelial cell adhesion molecules including intercellular cell adhesion molecule-1 (ICAM-1) and vascular cell adhesion molecule-1 (VCAM-1), which play a significant role in inflammation (Sherif et al., 2016).

Furthermore, prostaglandin synthesis is mediated by the cyclooxygenase enzyme (COX) which has the inducible isoform COX-2, which is expressed in response to inflammation as well as different stimuli involving cytokines as TNF- $\alpha$ and growth factors (Sherif, 2018). Moreover, chemokines are a large family of small cytokines and some of them are considered to be pro-inflammatory. CCL11 is a member of the CC chemokine family and is implicated in eosinophils recruitment into inflammation sites when inflammation occurred (Palomino and Marti, 2015).
On the other hand, the myeloperoxidase (MPO) enzyme, which catalyzes the conversion of hydrogen peroxide and chloride into hypochlorite, is stored in polymorphonuclear neutrophils and macrophages. In inflammatory processes it is released from activated neutrophils into the extracellular fluid. Thus, MPO could be considered as a pro-oxidative and proinflammatory marker (Loria et al., 2008).

Effects of CYP. Inflammation is implicated in the pathogenesis of CYP-induced HC (Arafa, 2009; Sherif et al., 2016), in which an inflammation of the urinary bladder associated with severe pain, bleeding, edema, and leukocyte infiltration occurs (Santos et al., 2010).

Many studies have documented that CYP injection induces a marked rise in the TNF- $\alpha$ levels in serum and bladder (Arafa, 2009; Sakthivel and Guruvayoorappan, 2015). IL-1 $\beta$ and IL-6 are other pro-inflammatory cytokines involved in the process of $\mathrm{HC}$ induced by CYP. Elevated bladder levels of IL- $1 \beta$ and IL-6 following CYP were noticed along with increased MPO activity (Arafa, 2009; Dietrich et al., 2015). Acrolein led to induction of the inflammatory cytokines through NF-kB activation, resulting in the production of cytokines like TNF- $\alpha$ and IL- 6 as well as ROS (Keles et al., 2014; Wang et al., 2012). Furthermore, the antiinflammatory cytokine IL-10, which has a cytoprotective effect via minimizing macrophage activation, as well as ROS production, was found to be markedly reduced in both bladder tissue and serum after CYP injection (Keles et al., 2014; Sherif, 2018).

On the other hand, ICAM-1 is a proinflammatory mediator that can result in the release of inflammatory factors via stimulating mast cells and adhesion of leukocytes to the inflammatory region (Zhang et al., 2016). The upregulation of bladder ICAM-1 levels was observed after CYP injection (Sherif et al., 2016). Moreover, VEGF, a mediator of angiogenesis and inflammation (Shaik-Dasthagirisaheb et al., 2013) was also involved in the pathophysiological mechanism of CYP-induced HC (Sherif et al., 2016). Elevated levels of bladder VEGF were found following injection of CYP, and this may be explained by its proinflammatory action via stimulating the release of TNF- $\alpha$ and other ILs (Cheppudira et al., 2008).

Meanwhile, the pro-inflammatory enzyme cyclooxygenase-2 (COX-2) is induced by cytokines 
Sherif, I. O. (2020). Uroprotective mechanisms of natural products against cyclophosphamide-induced urinary bladder toxicity: A comprehensive review. Acta Sci. Pol. Technol. Aliment., 19(3), 333-346. http://dx.doi.org/10.17306/J.AFS.2020.0832

like TNF- $\alpha$ and is involved in the pathogenesis of the CYP-induced HC. The COX-2 mRNA expression is upregulated in bladder tissue treated with CYP (Sherif, 2018). In addition, the inflammatory chemokine CCL11 has also been implicated in the pathogenesis of CYP-induced HC. It has been reported that CYP-induces a marked rise in levels of CCL11 in serum, and urinary bladder protein and mRNA expression (Abdi et al., 2018). However, a notable increase in the bladder MPO which is correlated with leukocyte infiltration in the urothelium has been documented following CYP administration (Moraes et al., 2013).

Effect of natural products. Many studies have confirmed that natural products could minimize the inflammation produced following CYP. Acacia ferruginea and curcumin showed a marked reduction in the serum TNF- $\alpha$ in animals injected with CYP (Arafa, 2009; Sakthivel and Guruvayoorappan, 2015). Resveratrol, a natural polyphenolic compound derived from grapes, and quercetin, a flavonoid found in food such as apples and berries, have been shown to have uroprotective effects via modulating inflammation in a model of CYP-induced HC. A marked decline in TNF- $\alpha$ and IL- 6 with an elevation in IL-10 level was found in the serum and bladder tissue of animals treated with resveratrol and quercetin (Keles et al., 2014; Sherif, 2018), while a significant downregulation of bladder COX-2 mRNA expression was reported with quercetin (Sherif, 2018).

Oleuropein is a phenolic compound obtained from olive leaves. It has the ability to protect the urinary bladder in an experimental model of CYP-induced HC through marked reduction of bladder VEGF levels and significant downregulation of bladder ICAM-1 mRNA expression (Sherif et al., 2016). The treatment of SAC showed a significant reduction in CCL11 in serum, bladder protein, and mRNA levels compared to animals treated with CYP (Abdi et al., 2018).

The quinovic acid glycosides purified fraction (QAPF) derived from Uncaria tomentosa (F: Rubiaceae) bark and roots, which have been utilized by the Asháninkas people for various diseases (Keplinger et al., 1998), was reported to have a uroprotective action against CYP-induced HC (Dietrich et al., 2015). A marked reduction in bladder IL-1 and MPO levels was observed with QAPF treatment (Dietrich et al.,
2015). Furthermore, the Caesalpinia pyramidalis Tul. (F: Fabaceae), a Brazilian tree and its inner bark extract possesse anti-inflammatory and antioxidant properties, as well as having the capability of reducing the bladder damage occurring in models of CYP-induced urotoxicity through marked reduction of bladder MPO content (Moraes et al., 2013). Moreover, the food coloring and spice agent curcumin has pharmacological properties including antioxidant and anti-inflammatory effects, which was evidenced by the marked reduction of bladder MPO level following CYP (Arafa, 2009).

\section{Role of the immune system}

It has been reported that the immune cytokine IL-2 plays a significant role in the development of monocytes and lymphocytes in addition to activation of the natural killer cells (NK) that produce interferongamma (IFN- $\gamma$ ), which subsequently stimulates macrophage activation and T-cell differentiation (Mah and Cooper, 2016; Sakthivel and Guruvayoorappan, 2015). Moreover, it has been documented that the hematopoietic growth factor Granulocyte-Macrophage Colony Stimulating Factor (GM-CSF) is essential for the regulation of hematopoietic cell (monocytes and macrophages) proliferation, differentiation and maturation (Bhattacharya et al., 2015).

Effects of CYP. Cyclophosphamide - CYP is an immunosuppressant agent and its impact on immune system cells has been studied. Cyclophosphamide CYP induced a marked reduction in IL-2, IFN- $\gamma$, and GM-CSF serum levels as reported in models of CYP-induced HC (Hamsa and Kuttan, 2011; Sakthivel and Guruvayoorappan, 2015).

Effects of natural products. The protective effect of Acacia ferruginea was reported to occur against bladder injury induced by CYP through an elevation in the serum levels of IL-2, IFN- $\gamma$, GM-CSF (Hamsa and Kuttan, 2012; Sakthivel and Guruvayoorappan, 2015) and the same effect was also seen after treatment with Indian medicinal plants Ipomoea obscura (F: Linn.) (Hamsa and Kuttan, 2011) and Tinospora cordifolia Miers (F: Menispermaceae) (Hamsa and Kuttan, 2012). 
Sherif, I. O. (2020). Uroprotective mechanisms of natural products against cyclophosphamide-induced urinary bladder toxicity: A comprehensive review. Acta Sci. Pol. Technol. Aliment., 19(3), 333-346. http://dx.doi.org/10.17306/J.AFS.2020.0832

\section{Role of apoptosis}

Apoptosis, widely known as programmed cell death, is exaggerated by oxidative stress (Kim et al., 2014). Caspase-3 is the executive caspase which is activated in both intrinsic and extrinsic pathways resulting in an apoptotic cell (Kyrylkova et al., 2012).

Effects of CYP. Apoptosis has a great impact on the pathogenesis of CYP-induced urinary injury (Kim et al., 2014). Apoptosis was confirmed following CYP in the bladder tissue via a marked rise in the caspase- 3 positive cells (Ayhanci et al., 2019; Kim et al., 2014).

Effects of natural products. In experimental models of CYP-induced HC, administration of DADS led to suppression of bladder apoptosis by a marked decline in the caspase-3 positive cells observed in bladder tissue (Kim et al., 2014).

\section{Role of DNA fragmentation}

The chief feature of apoptosis is DNA fragmentation which occurs during the late stages of apoptosis (Majtnerová and Roušar, 2018). Three assays were used to detect DNA fragmentation including; DNA ladder assay detecting the DNA fragment pattern, comet assay or single cell gel electrophoresis assay detecting the DNA damage in a single cell, and terminal deoxynucleotidyl transferase (TdT) dUTP Nick-End Labeling (TUNEL) assay which detected the apoptotic cells that undergo severe DNA degradation throughout the apoptosis late stages (Kyrylkova et al., 2012). In the comet assay, tail length, the migration extent of the DNA, and the percentage of the DNA content in the tail comet were shown to be related to the rate of the DNA breakage (Gore et al., 2016).

Effects of CYP. The toxic metabolites of CYP caused apoptosis in a rat's urinary bladder, which is associated with protein cleavage and DNA strand breakage (Gore et al., 2016; Tripathi and Jena, 2010). Cyclophosphamide - CYP injection resulted in a marked elevation in the oxidative stress, which induced a notable increase in DNA damage in the bladder. Bladder tissue from CYP treated animals exhibited a marked higher percentage of tail DNA content, length, and moment than in normal animals. Furthermore, the DNA ladder assay showed a marked increase in DNA fragmentation with low molecular weight DNA bands formation in the bladder tissue (Gore et al., 2016; Tripathi and Jena, 2010). Moreover, increased TUNEL positive cells was detected in bladder tissue following treatment with CYP (Kim et al., 2014; Tripathi and Jena, 2010).

Effects of natural products. In animal models of CYP-induced urotoxicity, treatment with thymoquinone showed a marked reduced percentage in tail DNA content, length, and moment confirming its antiapoptotic uroprotective effect via inhibition of DNA fragmentation and damage (Gore et al., 2016). Furthermore, administration of pomegranate, a medicinal plant in Indian culture, and DADS exhibited a marked reduction in bladder TUNEL positive cells (Kim et al., 2014; Mahmoudi et al., 2018).

\section{Role of uroplakins (Ups)}

The urothelium apical layer is composed of umbrella cells creating a distinctive asymmetric unit membrane (AUM) associated with hexagonal plaques uroplakins (Ups) expressed in normal urothelium (Kątnik-Prastowska et al., 2014; Manikandan et al., 2010). Uroplakins - UPs proteins have 4 types: Ia, Ib, II, and III which with tight junctions compose a specific membrane chamber with a sealed impermeable barrier in the bladder (Hu et al., 2000). When Ups proteins were subjected to reduction or destruction by toxic drugs or metabolites, an increase in bladder permeability occurred leading to the free passage of toxic substances in the urine, followed by inflammatory cell accumulation in the mucosa or submucosa (Choi et al., 2009; Kyung et al., 2011).

Effects of CYP. Cyclophosphamide - CYP caused a disturbance in the Ups expression as well as the tight junctions of the urinary bladder leading to hematuria and edema (Kyung et al., 2011). Many studies have documented a marked downregulation of UPs (II and III) protein and mRNA (Ia, Ib, II, and III) expressions in the bladder after CYP injection. Moreover, the protective mechanism of Mesna was documented via the upregulation of Ups (II and III) protein and mRNA (Ia, $\mathrm{Ib}$, II, and III) bladder expressions (Abdi et al., 2016; 2018; Choi et al., 2009; Kyung et al., 2011).

Cyclophosphamide - CYP induced a significant elevation of serum UpIIIa, indicating urothelial injury 
Sherif, I. O. (2020). Uroprotective mechanisms of natural products against cyclophosphamide-induced urinary bladder toxicity: A comprehensive review. Acta Sci. Pol. Technol. Aliment., 19(3), 333-346. http://dx.doi.org/10.17306/J.AFS.2020.0832

(Abdi et al., 2018) in which the CYP metabolite acrolein came in contact with the urothelium, leading to a detachment of the superficial cells that contain UPI -IIa and consequently, a disruption of the normal barrier of the bladder occurred (Abdi et al., 2016; 2018).

Effects of natural products. One of the natural products that act through Ups is SAC extracted from aged garlic. SAC induced an uroprotective effect against CYP-induced HC through a marked upregulation of mRNA and protein expressions of Up II and Up IIIa in urinary bladder, while the serum level of Up IIIa was markedly decreased (Abdi et al., 2016; 2018).

\section{Role of purinergic signaling and muscarinic receptors}

The main muscle component of the urinary bladder wall is the detrusor smooth muscle which has the ability to contract and relax determining bladder function through micturition and filling. The detrusor functional changes were reported in bladder disorders (Andersson and Arner, 2004). Moreover, the detrusor muscle contains many receptors, the $\mathrm{M} 2$ receptor subtype is a predominant muscarinic receptor while the M3 receptor subtype is the most vital to mediate the cholinergic contractile response (Andersson and Arner, 2004). Bladder contraction is controlled via the parasympathetic nervous system by the action of Ach on muscarinic receptors in the detrusor (Aronsson et al., 2012).

On the other hand, purinergic receptors are classified into $\mathrm{P} 1$ and $\mathrm{P} 2$ receptors. $\mathrm{P} 1$ receptors are adenosine selective with 4 subtypes, including P1: A1, A3, $\mathrm{A} 2 \mathrm{~A}, \mathrm{~A} 2 \mathrm{~B}$ and has been reported to be expressed in the body, including the urinary bladder. Meanwhile, P2 receptors are ATP (adenosine 5'-triphosphate) selective and subdivided into $\mathrm{P} 2 \mathrm{X}$, responsible for bladder contractile function, and $\mathrm{P} 2 \mathrm{Y}$, responsible for bladder relaxation activity. Both receptors are involved in inflammation and tissue damage (Aronsson et al., 2012; Winder et al., 2014).

Moreover, ATP is a biological molecule which acts as a neurotransmitter in nerves supplying the urinary bladder, and has a role in the sensation of bladder fullness and disorders (Benarroch, 2010; Burnstock, 2014). It exerts its action via the $\mathrm{P} 2$ receptor, and it can be metabolized by the action of bladder ectonucleotidase, forming adenosine which could affect the P1 receptor (Aronsson et al., 2012; Winder et al., 2014).

During mechanical deformation as a result of stretching, stress, hypoxia, and stimulation by different agents, ATP could be released from any cell types, either neuronal or nonneuronal (Bodin and Burnstock, 2001). Any alterations in purinergic receptor expression, as well as ATP release, may result in bladder disorders (Winder et al., 2014).

Effects of CYP. It was reported that CYP treatment exhibited a marked reduction in Ach-induced cholinergic contraction (Barut et al., 2019). A study of Al-Yahya and his colleagues reported that the responsiveness of the isolated urinary bladder rings from animals treated with CYP to Ach was markedly decreased when compared to the control group (Al-Yahya et al., 2009). During cystitis, type I collagen was upregulated and deposited leading to bladder wall thickness and this decreases the tension force of detrusor wall strips to stimuli (Liu et al., 2015).

On the other hand, purinergic signaling is involved in the pathogenesis of CYP-induced bladder toxicity, and activation of the purinergic receptor has been linked with ROS and pro-inflammatory cytokine release (Gonzalez et al., 2015). A study by Dietrich et al. (2015) documented upregulation of P2X7 receptors in the bladder tissue of CYP-injected animals, confirming its relationship with the infiltration of neutrophil and production of proinflammatory cytokines (Dietrich et al., 2015). Also, it was reported that CYP induced marked upregulation of bladder protein expressions of P2X2, P2X3, M2 and M3 receptors (Lee et al., 2016).

Increased urinary bladder ATP expression has been observed in CYP treated animals, explained as a response of the bladder to extracellular stimuli, and this may contribute to increased urges and micturitions (Aronsson et al., 2012; Gonzalez et al., 2015). Contradictory results were reported by Arafa in 2009 who reported a marked reduction in bladder ATP in CYP treated rats compared to normal rats explaining that this energy starvation will lead to the urothelial tissue being exposed to the harmful effects of CYP (Arafa, 2009). 
Sherif, I. O. (2020). Uroprotective mechanisms of natural products against cyclophosphamide-induced urinary bladder toxicity: A comprehensive review. Acta Sci. Pol. Technol. Aliment., 19(3), 333-346. http://dx.doi.org/10.17306/J.AFS.2020.0832

Effects of natural products. The QAPF showed significant downregulation of P2X7R bladder expression immunohistochemically, and this could be explained by the reduction in neutrophil migration in the inflamed bladder (Dietrich et al., 2015). The traditional Chinese medicine called Ba-Wei-Die-Huang-Wan (BWDHW) has been reported to inhibit the upregulation of $\mathrm{P} 2 \mathrm{X} 2, \mathrm{P} 2 \mathrm{X} 3, \mathrm{M} 2$ and $\mathrm{M} 3$ protein expressions in bladder following CYP injection (Lee et al., 2016). Arafa reported in 2009 that curcumin administration before CYP exhibited a marked elevation in bladder ATP and explained this by increased ATP synthesis as curcumin was documented to increase the activity of ATP synthase (Arafa, 2009).

On the other hand, pretreatment with Gum Arabic showed a marked increase in the responsiveness of the isolated urinary bladder rings to Ach when compared with the sole administration of CYP confirming that Gum Arabic has a significant protective role on the bladder against CYP-induced bladder injury (Al-Yahya et al., 2009).

\section{Role of CYP metabolism by CytP450}

The enzyme CytP450 is responsible for drug metabolism through catalyzing the oxidative biotransformation of most drugs and other xenobiotics. Drug metabolism happens in the liver and also in other extrahepatic sites in the body. The drug metabolism primary site is the liver and is carried out through either phase I, phase II reactions, or both. In the phase I reaction, oxidation occurred and was catalyzed by the CytP450 which is assigned a family number (CytP1, CytP2) and a subfamily letter (e.g., CytP 1A, CytP 2D) and differentiated by a number for the isoform or individual enzyme (e.g., CytP 1A1, CytP 2D6) (McDonnell and Dang, 2013).

Effects of CYP. Cyclophosphamide - CYP is oxidatively activated by the hepatic microsomal CytP450, and mainly CytP2C11, CytP2B and CytP3A. CytP2B, and $\mathrm{CytP} 2 \mathrm{C}$ metabolized $\mathrm{CYP}$ into acrolein and phosphoramide mustard active metabolites while CytP3A converts CYP into dechloroethyl CYP and chloroacetaldehyde (Yu and Waxman, 1996). Therefore, any modulation of CytP450 will impact on the detoxification of CYP (Kim et al., 2014).
Kim et al. (2014) reported that CYP injection showed a marked decrease in the protein expression of CytP2C11 level, which is the main CytP in the liver of rats, in addition to a significant elevation of the protein expression level of CytP2B1/2 compared to the control group.

Effects of natural products. The experiment carried out by Kim and his colleagues in 2014 explored the uroprotective effects of DADS via CytP2C11 inhibition and CytP3A1 induction and this coordinated with the reduced accumulation of acrolein protein adducts in the urinary bladder (Kim et al., 2014). DADS administration with CYP showed that the expression of CytP2B1/2 and CytP3A1 protein levels were markedly increased whereas the expression level of CytP2C11 was significantly decreased when compared with the CYP group (Kim et al., 2014).

\section{CONCLUSION}

Cyclophosphamide has a known urotoxic effect that causes frustration for physicians with its clinical use and enforces them to find a way to minimize this side effect. Experimental results have raised hopes of offering novel candidates for the treatment of CYP-induced $\mathrm{HC}$ as medicinal plants and supporting their use as either an adjunctive therapy with CYP or as an alternative therapy to reduce cystitis induced by CYP. Medicinal plants are capable of modulating oxidative stress, inflammation, the immune system, apoptosis, DNA fragmentation, uroplakins, purinergic signaling and muscarinic receptors, and CytP450 metabolism. However, further studies are encouraged to discover other medicinal plants with new uroprotective mechanisms against CYP-induced HC.

\section{REFERENCES}

Abdi, S. A. H., Afjal, M. A., Najmi, A. K., Raisuddin, S. (2018). S-allyl cysteine ameliorates cyclophosphamideinduced downregulation of urothelial uroplakin IIIa with a concomitant effect on expression and release of CCL11 and TNF- $\alpha$ in mice. Pharm. Rep., 70(4), 769-776.

Abdi, S. A. H., Najmi, A. K., Raisuddin, S. (2016). Cyclophosphamide-induced down-regulation of uroplakin II in the mouse urinary bladder epithelium is prevented 
Sherif, I. O. (2020). Uroprotective mechanisms of natural products against cyclophosphamide-induced urinary bladder toxicity: A comprehensive review. Acta Sci. Pol. Technol. Aliment., 19(3), 333-346. http://dx.doi.org/10.17306/J.AFS.2020.0832

by S-allyl cysteine. Basic Clin. Pharm. Toxicol., 119(6), 598-603.

Abraham, P., Isaac, B., Ramamoorthy, H., Natarajan, K. (2011). Oral glutamine attenuates cyclophosphamideinduced oxidative stress in the bladder but does not prevent hemorrhagic cystitis in rats. J. Med. Toxicol., 7(2), $118-124$.

Al-Yahya, A. A., Al-Majed, A. A., Gado, A. M., Daba, M. H., Al-Shabanah, O. A., El-Azab, A. S., Abd-Allah, A. R. (2009). Acacia Senegal gum exudate offers protection against cyclophosphamide-induced urinary bladder cytotoxicity. Oxid. Med. Cell. Long., 2(4), 207-213.

Andersson, K.-E., Arner, A. (2004). Urinary bladder contraction and relaxation: physiology and pathophysiology. Phys. Rev., 84(3), 935-986.

Arafa, H. M. (2009). Uroprotective effects of curcumin in cyclophosphamide-induced haemorrhagic cystitis paradigm. Basic Clin. Pharm. Toxicol., 104(5), 393-399.

Aronsson, P., Johnsson, M., Vesela, R., Winder, M., Tobin, G. (2012). Adenosine receptor antagonism suppresses functional and histological inflammatory changes in the rat urinary bladder. Auton. Neurosci., 171(1-2), 49-57.

Ayhanci, A., Tanriverdi, D. T., Sahinturk, V., Cengiz, M., Appak-Baskoy, S., Sahin, I. K. (2019). Protective effects of boron on cyclophosphamide-induced bladder damage and oxidative stress in rats. Biol. Trace Elem. Res., 1-8.

Barut, E. N., Engin, S., Barut, B., Kaya, C., Kerimoglu, G., Ozel, A., Kadioglu, M. (2019). Uroprotective effect of ambroxol in cyclophosphamide-induced cystitis in mice. Int. Urol. Nephrol., 51(5), 803-810.

Benarroch, E. E. (2010). Adenosine triphosphate: a multifaceted chemical signal in the nervous system. Neurology, 74(7), 601-607.

Bhatia, K., Ahmad, F., Rashid, H., Raisuddin, S. (2008). Protective effect of S-allylcysteine against cyclophosphamide-induced bladder hemorrhagic cystitis in mice. Food Chem. Toxicol., 46(11), 3368-3374.

Bhattacharya, P., Thiruppathi, M., Elshabrawy, H. A., Alharshawi, K., Kumar, P., Prabhakar, B. S. (2015). GM-CSF: An immune modulatory cytokine that can suppress autoimmunity. Cytokine, 75(2), 261-271.

Birben, E., Sahiner, U. M., Sackesen, C., Erzurum, S., Kalayci, O. (2012). Oxidative stress and antioxidant defense. World Aller. Org. J., 5(1), 9-19.

Bodin, P., Burnstock, G. (2001). Purinergic signalling: ATP release. Neurochem. Res., 26(8-9), 959-969.

Bryan, H. K., Olayanju, A., Goldring, C. E., Park, B. K. (2013). The Nrf2 cell defence pathway: Keap1-dependent and-independent mechanisms of regulation. Biochem. Pharm., 85(6), 705-717.
Burnstock, G. (2014). Purinergic signalling in the urinary tract in health and disease. Purin. Signal., 10(1), 103155.

Büyüknacar, H. S., Kumcu, E. K., Göçmen, C., Önder, S. (2008). Effect of phosphodiesterase type 4 inhibitor rolipram on cyclophosphamide-induced cystitis in rats. Eur. J. Pharmacolog., 586(1-3), 293-299.

Cheppudira, B. P., Girard, B. M., Malley, S. E., Schutz, K. C., May, V., Vizzard, M. A. (2008). Upregulation of vascular endothelial growth factor isoform VEGF-164 and receptors (VEGFR-2, Npn-1, and Npn-2) in rats with cyclophosphamide-induced cystitis. Am. J. Phys.-Renal Phys., 295(3), F826-F836.

Choi, S. H., Byun, Y., Lee, G. (2009). Expressions of uroplakins in the mouse urinary bladder with cyclophosphamide-induced cystitis. J. Korean Med. Sci., 24(4), 684-689.

Dietrich, F., Martins, J. P., Kaiser, S., Silva, R. B. M., Rockenbach, L., Edelweiss, M. I. A., ..., Battastini, A. M. O. (2015). The quinovic acid glycosides purified fraction from Uncaria tomentosa protects against hemorrhagic cystitis induced by cyclophosphamide in mice. PloS One 10(7), e0131882.

Eser, N., Göçmen, C. Erdoğan, Ş., Büyüknacar, H. S. G., Kumcu, E. K., Açıkalın A., Önder, S. (2012). Effect of silymarin on bladder overactivity in cyclophosphamideinduced cystitis rat model. Phytomedicine, 19(8-9), 840-845.

Gonzalez, E. J., Peterson, A., Malley, S. Daniel, M., Lambert, D., Kosofsky, M., Vizzard, M. A. (2015). The effects of tempol on cyclophosphamide-induced oxidative stress in rat micturition reflexes. Sci. World J. ID 545048. https://doi.org/10.1155/2015/545048

Gore, P. R., Prajapati, C. P., Mahajan, U. B., Goyal, S. N., Belemkar, S., Ojha, S., Patil, C. R. (2016). Protective effect of thymoquinone against cyclophosphamideinduced hemorrhagic cystitis through inhibiting DNA damage and upregulation of Nrf2 expression. Int. J. Biol. Sci., 12(8), 944.

Gulati, K., Guhathakurta, S., Joshi, J., Rai, N., Ray, A. (2016). Cytokines and their role in health and disease, a brief overview. MOJ Immunol., 4(2), 1-9.

Hamsa, T., Kuttan, G. (2011). Protective role of Ipomoea obscura (L.) on cyclophosphamide-induced uro-and nephrotoxicities by modulating antioxidant status and proinflammatory cytokine levels. Inflammopharmacology, 19(3), 155-167.

Hamsa, T., Kuttan, G. (2012). Tinospora cordifolia ameliorates urotoxic effect of cyclophosphamide by modulating 
Sherif, I. O. (2020). Uroprotective mechanisms of natural products against cyclophosphamide-induced urinary bladder toxicity: A comprehensive review. Acta Sci. Pol. Technol. Aliment., 19(3), 333-346. http://dx.doi.org/10.17306/J.AFS.2020.0832

GSH and cytokine levels. Exp. Toxicol. Pathol., 64(4), 307-314.

Hu, P., Deng, F.-M., Liang, F.-X., Hu, C.-M., Auerbach, A. B., Shapiro, E., ..., Sun, T.-T. (2000). Ablation of uroplakin III gene results in small urothelial plaques, urothelial leakage, and vesicoureteral reflux. J. Cell Biol., 151(5), 961-972.

Kątnik-Prastowska, I., Lis, J., Matejuk, A. (2014). Glycosylation of uroplakins. Implications for bladder physiopathology. Glycocon. J., 31(9), 623-636.

Keles, I., Bozkurt, M. F., Cemek, M., Karalar, M., Hazini, A., Alpdagtas, S., ..., Buyukokuroglu, M. E. (2014). Prevention of cyclophosphamide-induced hemorrhagic cystitis by resveratrol: a comparative experimental study with mesna. Int. Urol. Nephrol., 46(12), 2301-2310.

Keplinger, K., Laus, G., Wurm, M., Dierich, M. P., Teppner, H. (1998). Uncaria tomentosa (Willd.) DC. - ethnomedicinal use and new pharmacological, toxicological and botanical results. J. Ethnopharm., 64(1), 23-34.

Kim, S.-H., Lee, I.-C., Baek, H.-S., Shin, I.-S., Moon, C., Bae, C.-S., ..., Kim, H.-C. (2014). Mechanism for the protective effect of diallyl disulfide against cyclophosphamide acute urotoxicity in rats. Food Chem. Toxicol., $64,110-118$

Kyrylkova, K., Kyryachenko, S., Leid, M., Kioussi, C. (2012). Detection of apoptosis by TUNEL assay. In Ch. Kioussi (Ed.), Odontogenesis. Methods and protocols (pp. 41-47). Springer.

Kyung, Y. S., Park, H. Y., Lee, G. (2011). Preservation of uroplakins by 2-mercaptoethanesulfonate in cyclophosphamide-induced rat cystitis. Arch. Toxicol., 85(1), $51-57$.

Lee, W.-C., Wu, C.-C., Chuang, Y.-C., Tain, Y.-L., Chiang, P.-H. (2016). Ba-Wei-Die-Huang-Wan (Hachimi-jiogan) can ameliorate cyclophosphamide-induced ongoing bladder overactivity and acidic adenosine triphosphate solution-induced hyperactivity on rats prestimulated bladder. J. Ethnopharm., 184, 1-9.

Liu, M., Shen, S., Kendig, D. M., Mahavadi, S., Murthy, K. S., Grider, J. R., Qiao, L.-Y. (2015). Inhibition of NMDAR reduces bladder hypertrophy and improves bladder function in cyclophosphamide induced cystitis. J. Urol., 193(5), 1676-1683.

Loria, V., I. Dato, F. Graziani, L. M. Biasucci. (2008). Myeloperoxidase: A new biomarker of inflammation in ischemic heart disease and acute coronary syndromes. Mediators. Inflamm., ID 135625. http://dx.doi. org/10.1155/2008/135625
Mah, A. Y., Cooper, M. A. (2016). Metabolic regulation of natural killer cell IFN- $\gamma$ production. Crit. Rev. Immunol., 36(2).

Mahmoudi, N., Eftekharzadeh, S., Golmohammadi, M., Khorramirouz, R., Hashemi, J., Kashani, Z., ..., Kajbafzadeh, A.-M. (2018). Alleviation of cyclophosphamide-induced hemorrhagic cystitis by dietary pomegranate: A comparative experimental study with mesna. J. Ped. Hemat./Oncol., 40(8), 609-615.

Majtnerová, P., Roušar, T. (2018). An overview of apoptosis assays detecting DNA fragmentation. Mol. Biol. Rep., 45(5), 1469-1478.

Manikandan, R., Kumar, S., Dorairajan, L. N. (2010). Hemorrhagic cystitis: a challenge to the urologist. Ind. J. Urol., 26(2), 159.

Matz, E. L., Hsieh, M. H. (2017). Review of advances in uroprotective agents for cyclophosphamide-and ifosfamide-induced hemorrhagic cystitis. Urology, 100, 16-19.

McDonnell, A. M., Dang, C. H. (2013). Basic review of the cytochrome p450 system. J. Adv. Pract. Oncol., 4(4), 263.

Mohammad, M. K., Avila, D., Zhang, J., Barve, S., Arteel, G., McClain, C., Joshi-Barve, S. (2012). Acrolein cytotoxicity in hepatocytes involves endoplasmic reticulum stress, mitochondrial dysfunction and oxidative stress. Toxicol. Appl. Pharm., 265(1), 73-82.

Moraes, J. P., Pereira, D. S., Matos, A. S., Santana, D. G., Santos, C. A., Estevam, C. S., ..., Camargo, E. A. (2013). The ethanol extract of the inner bark of Caesalpinia pyramidalis (Tul.) reduces urinary bladder damage during cyclophosphamide-induced cystitis in rats. Sci. World J. ID 694010. http://dx.doi.org/10.1155/2013/694010

Ozcan, A., Korkmaz, A., Oter, S., Coskun, O. (2005). Contribution of flavonoid antioxidants to the preventive effect of mesna in cyclophosphamide-induced cystitis in rats. Arch. Toxicol., 79(8), 461-465.

Palomino, D. C. T., Marti, L. C. (2015). Chemokines and immunity. Einstein (Sao Paulo), 13(3), 469-473.

Raju, N., Sakthivel, K. M., Kannan, N., Prabhu, V. V., Guruvayoorappan, C. (2015). Cuscuta chinensis ameliorates immunosuppression and urotoxic effect of cyclophosphamide by regulating cytokines-GM-CSF and TNF-alpha. Appl. Biochem. Biotechnol., 176(3), 742-757.

Robertson, L.-M., Clark, A. (2016). Looking beyond the angiotensin receptor blocker: A case of anaphylaxis to mesna. Ann. Allerg. Asthma Immunol., 117(3), 324-325.

Rouissi, K., Hamrita, B., Kouidi, S., Messai, Y., Jaouadi, B., Hamden, K., ..., Elgaaied, A. B. (2011). In vivo prevention of bladder urotoxicity: Purified hydroxytyrosol 
Sherif, I. O. (2020). Uroprotective mechanisms of natural products against cyclophosphamide-induced urinary bladder toxicity: A comprehensive review. Acta Sci. Pol. Technol. Aliment., 19(3), 333-346. http://dx.doi.org/10.17306/J.AFS.2020.0832

ameliorates urotoxic effects of cyclophosphamide and buthionine sulfoximine in mice. Int. J. Toxicol., 30(4), 419-427.

Sadir, S., Deveci, S., Korkmaz, A., Oter, S. (2007). Alpha-tocopherol, beta-carotene and melatonin administration protects cyclophosphamide-induced oxidative damage to bladder tissue in rats. Cell Biochem. Func.: Cell. Biochem. Modul. Active Agents Disease, 25(5), 521-526.

Saito, Y., Kumamoto, T., Shiraiwa, M., Sonoda, T., Arakawa, A., Hashimoto, H., ..., Terakado, H. (2018). Cyclophosphamide-induced hemorrhagic cystitis in young patients with solid tumors: A single institution study. Asia-Pacific J. Clin. Oncol., 14(5), e460-e464.

Sakthivel, K., Guruvayoorappan, C. (2015). Acacia ferruginea inhibits cyclophosphamide-induced immunosuppression and urotoxicity by modulating cytokines in mice. J. Immunotoxicol., 12(2), 154-163.

Sakthivel, K. M., Guruvayoorappan, C. (2013). Acacia ferruginea inhibits tumor progression by regulating inflammatory mediators-(TNF- $\alpha$, iNOS, COX-2, IL-1 $\beta$, IL-6, IFN- $\gamma$, IL-2, GM-CSF) and pro-angiogenic growth factor-VEGF. Asian Pac. J. Cancer Prev., 14(6), 3909-3919.

Santos, A. A., Leal, P. C., Edelweiss, M. I., Lopes, T. G., Calixto, J. B., Morrone, F. B., Campos, M. M. (2010). Effects of the compounds MV8608 and MV8612 obtained from Mandevilla velutina in the model of hemorrhagic cystitis induced by cyclophosphamide in rats. NaunynSchmiedeberg's Arch. Pharm., 382(5-6), 399-407.

Sekeroğlu, V., Aydin, B., Sekeroğlu, Z. (2011). Viscum album L. extract and quercetin reduce cyclophosphamideinduced cardiotoxicity, urotoxicity and genotoxicity in mice. Asian Pac. J. Cancer Prev., 12(11), 2925-2931.

Shaik-Dasthagirisaheb, Y., Varvara, G., Murmura, G., Saggini, A., Potalivo, G., Caraffa, A., ..., Conti, F. (2013). Vascular endothelial growth factor (VEGF), mast cells and inflammation. SAGE Publ. Sage UK: London, England.

Sherif, I. O. (2018). Uroprotective mechanism of quercetin against cyclophosphamide-induced urotoxicity: Effect on oxidative stress and inflammatory markers. J. Cell. Biochem., 119(9), 7441-7448.

Sherif, I. O., Nakshabandi, Z. M., Mohamed, M. A., Sarhan, O. M. (2016). Uroprotective effect of oleuropein in a rat model of hemorrhagic cystitis. Int. J. Biochem. Cell Biol., 74, 12-17.
Sinanoglu, O., Yener, A. N., Ekici, S., Midi, A., Aksungar, F. B. (2012). The protective effects of spirulina in cyclophosphamide induced nephrotoxicity and urotoxicity in rats. Urology, 80(6), 1392.E1-1392.E6. http://dx.doi. org/10.1016/j.urology.2012.06.053

Taha, N. R., Amin, H. A., Sultan, A. A. (2015). The protective effect of Moringa oleifera leaves against cyclophosphamide-induced urinary bladder toxicity in rats. Tissue Cell, 47(1), 94-104.

Topal, T., Oztas, Y., Korkmaz, A., Sadir, S., Oter, S., Coskun, O., Bilgic, H. (2005). Melatonin ameliorates bladder damage induced by cyclophosphamide in rats. J. Pineal Res., 38(4), 272-277.

Tripathi, D., Jena, G. (2010). Effect of melatonin on the expression of Nrf2 and NF- $\kappa \mathrm{B}$ during cyclophosphamideinduced urinary bladder injury in rat. J. Pineal Res., 48(4), 324-331.

Uysal, E., Y1lmaz, H. R., Ugan, Y., Altuntas, A., Dogru, A., Kutlucan, A., Tunc, S. E. (2015). Protective effects of caffeic acid phenethyl ester on cyclophosphamide-induced hemorrhagic cystitis in rats. J. Biochem. Molecular Toxicol., 29(12), 559-563.

Virág, L., Szabo, E., Gergely, P., Szabo, C. (2003). Peroxynitrite-induced cytotoxicity: mechanism and opportunities for intervention. Toxicol. Lett., 140, 113-124.

Wang, C.-C., Weng, T.-I., Wu, E.-T., Wu, M.-H., Yang, R.-S., Liu, S.-H. (2012). Involvement of interleukin-6-regulated nitric oxide synthase in hemorrhagic cystitis and impaired bladder contractions in young rats induced by acrolein, a urinary metabolite of cyclophosphamide. Toxicol. Sci., 131(1), 302-310.

Winder, M., Tobin, G., Zupančič, D., Romih, R. (2014). Signalling molecules in the urothelium. Biomed Res. Int. 297295. http://dx.doi.org/10.1155/2014/297295

Yu, L., Waxman, D. J. (1996). Role of cytochrome P450 in oxazaphosphorine metabolism. Deactivation via N-dechloroethylation and activation via 4-hydroxylation catalyzed by distinct subsets of rat liver cytochromes P450. Drug Metab. Disp., 24(11), 1254-1262.

Zhang, X., He, H., Lu, G., Xu, T., Qin, L., Wang, X., Jin, X., ..., Shen, Z. (2016). Specific inhibition of ICAM-1 effectively reduces bladder inflammation in a rat model of severe non-bacterial cystitis. Sci. Rep., 6, 35672. 